\title{
Albumin Telur Sebagai Lem pada Operasi Cangkok Konjungtiva
}

\author{
R. Angga Kartiwa, Iwan Sovani, Sutarya Enus, Arief Boediono, Retti N. Miraprahesti \\ Departemen Ilmu Kesehatan Mata Fakultas Kedokteran Universitas Padjadjaran \\ Rumah Sakit Mata Cicendo Bandung
}

\begin{abstract}
Abstrak
Cangkok konjungtiva sudah lama digunakan pada bidang oftalmologi. Metode yang digunakan saat ini untuk menempelkan cangkok konjungtiva adalah menggunakan teknik jahitan dan lem fibrin. Pada penelitian ini dilakukan uji coba menggunakan lem albumin pada cangkok konjungtiva kelinci sebagai alternatif lain selain menggunakan teknik jahitan dalam penempelan cangkok konjungtiva. Tujuan penelitian adalah membandingkan penyembuhan luka cangkok konjungtiva bulbi antara teknik lem albumin dan jahitan pada mata kelinci. Dilakukan animalexperimental study pada 32 mata (16 ekor kelinci) di PT. Bio Farma (Persero) dan laboratorium Histologi, Fakultas Kedokteran Universitas Padjadjaran dari bulan Maret 2014-Juli 2014, terbagi kelompok teknik lem albumin dan teknik jahitan. Dilakukan pemeriksaan meliputi perbandingan derajat perlekatan cangkok konjungtiva bulbi pada teknik lem albumin dan teknik jahitan yang diamati hari-1 pascabedah serta dilakukan pemeriksaan histologis secara mikroskopik untuk mendapatkan data celah luka yang diamati 10 menit dan hari-7 pascabedah. Analisis data dilakukan dengan Mann-Whitney test for small sample. Hasil penelitian memperlihatkan perlekatan cangkok konjungtiva bulbi secara bermakna lebih kuat pada teknik lem albumin (derajat 4) dibanding dengan teknik jahitan (derajat 2 dan 3) pada hari-1 pascabedah dengan nilai $\mathrm{p}=0,000$ serta terdapat perbedaan celah luka (wound gap) bermakna antara teknik lem albumin $(0-0,33 \mu \mathrm{m})$ dan jahitan $(5,33-14 \mu \mathrm{m})(\mathrm{p}=0,0005)$ pada cangkok konjungtiva dilihat sepuluh menit pascabedah dan pada hari-7 pascabedah untuk teknik lem albumin $(0 \mu \mathrm{m})$ dan teknik jahitan $(0,33-4 \mu \mathrm{m})$ dengan nilai $\mathrm{p}=0,0005$. Simpulan penelitian ini adalah derajat perlekatan jaringan cangkok pada teknik lem albumin lebih baik dibanding dengan jahitan hari-1 pascabedah, sedangkan celah luka lebih kecil pada teknik lem albumin dibanding dengan teknik jahitan pada pengamatan 10 menit dan hari-7 pascabedah. [MKB. 2016;48(4):241-8]
\end{abstract}

Kata kunci: Jahitan, lem albumin, penyembuhan luka konjungtiva

\section{Egg Albumin as Adhesive in Conjunctival Graft Surgery}

\begin{abstract}
CConjunctival graft has been frequently used in the field of ophthalmology. The frequently used methods to attach a conjunctival graft are suture technique and the use of fibrin glue. This study was to investigate albumin glue as an alternative to suture technique in attaching conjunctival grafts in rabbits. The aim of this study was to compare the conjunctival wound healing between albumin glue and suture technique in rabbit eye as a model. This was an experimental animal study that included 32 eyes (16 rabbits) conducted at PT. Bio Farma (Persero) and the Histology Laboratory, Faculty of Medicine, Universitas Padjadjaran from March 2014 to July 2104. The subjects in this study were divided into albumin glue group and suture technique group. The examinations were comparison of conjunctival graft attachment and histologic microscopic examination to assess the wound gap. Data analysis was performed statistically using Mann-Whitney test for small sample. The statistical analysis results showed that the graft attachment was significantly better when using albumin glue (grade 4) compared to suture (grade 2-3) on day- 1 after surgery $(\mathrm{p}=0.000)$. The wound gap was smaller using albumin glue $(0-0,33 \mu \mathrm{m}$ versus $5,33-14 \mu \mathrm{m}$; p0.0005) 10 minutes after surgery and $0 \mu \mathrm{m}$ versus $0.33-4 \mu \mathrm{m}, \mathrm{p} 0,0005$, on day-7 after surgery. In conclusion, graft attachment using albumi $\mathrm{n}$ glue is better and the wound gap is smaller when using albumin glue compared to the suture technique. [MKB. 2016;48(4):241-8]
\end{abstract}

Key words: Albumin glue, conjunctival wound healing, suture

Korespondensi: R. Angga Kartiwa, dr., Sp.M(K)., M.Kes , Departemen Ilmu Kesehatan Mata Fakultas Kedokteran Unpad/PMN Rumah Sakit Mata Cicendo Bandung Jalan Cicendo No. 4 Bandung, mobile 0811248818, e-mail anggakartiwa@gmail.com 


\section{Pendahuluan}

Teknik cangkok konjungtiva pada operasi pterigium pertama kali dilakukan pada tahun 1960. ${ }^{1}$ Teknik ini merupakan standar terapi pada operasi pterigium. ${ }^{2}$ Pterigium merupakan masalah kesehatan mata di Indonesia yang terletak di ekuator dan beriklim tropis. Teknik cangkok konjungtiva bulbi dapat menurunkan angka tumbuh ulang pascabedah pterigium, namun banyak menimbulkan ketidakpuasan bagi operator dan penderita akibat jahitan. ${ }^{3}$ Metode yang digunakan saat ini untuk menempelkan cangkok konjungtiva selain mempergunakan jahitan, dapat juga menggunakan lem fibrin. ${ }^{4}$

Penempelan cangkok konjungtiva bulbi menggunakan teknik jahitan merupakan bedah mikro yang rumit, juga membutuhkan tingkat pembelajaran operator tinggi, waktu operasi dan penyembuhan luka berlangsung lama, serta dapat menimbulkan komplikasi akibat jahitan berupa retraksi jaringan cangkok, pembentukan granuloma, proses infeksi, serta kematian pada jaringan cangkok. Tambahan trauma disebabkan oleh jarum, tarikan benang simpul jahitan akan merusak jaringan cangkok yang dapat mengakibatkan penempelan jaringan cangkok kurang baik. Kerugian lain adalah manipulasi jaringan lebih banyak sehingga terjadi adhesi jaringan cangkok dan penyembuhan berjalan lambat. ${ }^{3,5}$ Albumin merupakan cairan jernih yang berada dalam sebuah telur. ${ }^{6}$ Penyebab albumin dapat menyembuhkan luka bakar dikarenakan albumin merupakan bentuk kolagen yang alami. ${ }^{7}$ Kolagen merupakan salah satu komponen utama matriks ekstraseluler (ECM) yang menunjang pertumbuhan sel dan jaringan. Di samping kemampuan menunjang, ECM itu secara kuat memengaruhi perkembangan embrio, juga alur migrasi sel, sinyal penghidupan, dan memasok growth factor. ${ }^{4}$

Beberapa protein pada albumin terdiri atas ovalbumin, ovotransferin, ovomukoid, ovomusin, lisozim dan avidin serta sistatin. ${ }^{6}$ Ovalbumin merupakan protein terbanyak dalam albumin dan berperan sebagai substrat sel adhesi yang berfungsi menunjang attachment dan adhesi sel. ${ }^{8-10}$

Transglutaminase jaringan yang terdapat pada permukaan sel konjungtiva berperan dalam proses adhesi sel, juga dapat berinteraksi dengan ECM, serta berperan dalam proses penyembuhan luka. Ikatan transglutaminase dengan beberapa matrik protein dapat meningkatkan adhesi sel.6,11

\section{Metode}

Penelitian ini merupakan penelitian animal experimental study untuk mengetahui derajat perlekatan jaringan cangkok konjungtiva kelinci terhadap jaringan dasarnya (sklera) serta perbandingan celah luka (wound gap) antara teknik lem albumin dan jahitan. Kriteria inklusi kelinci New Zealand White biakan Bio Farma umur 2-3 bulan, bobot 2-2,5 $\mathrm{kg}$, sehat fisik (termasuk kesehatan kedua matanya), albumin telur bebek biakan lokal sehat yang berasal dari telur berumur tidak lebih dari 3 hari. Kriteria eksklusi adalah memiliki dua mata dengan kelainan anatomi bawaan yang terlihat secara umum, hanya memiliki satu mata yang sehat, terjadi penurunan berat badan saat dikarantina.

Penelitian dilaksanakan setelah mendapat persetujuan dari Komisi Kesejahteraan dan Penggunaan Hewan Laboratorium (Institutional Animal Care and Use Committee) PT. Bio Farma (Persero). Tempat penelitian di PT Bio Farma Bandung dan Departemen Histologi Fakultas Kedokteran Universitas Padjadjaran, periode Maret-Juli 2014. Subjek penelitian 16 ekor kelinci (32 mata) yang sesuai kriteria inklusi serta dikarantina selama satu minggu lebih yang terbagi secara acak dalam dua kelompok, yaitu kelompok I: teknik lem albumin kemudian teknik jahitan; kelompok II: teknik jahitan lalu teknik lem albumin. Pelaksanaan operasi yang dilakukan meliputi pembuatan cangkok konjungtiva, penempelan cangkok pada sklera yang terbuka mata yang sama menggunakan lem albumin yang dibuat secara steril dan teknik jahitan menggunakan benang vycril 8-0 sebanyak 3 buah. Derajat perlekatan cangkok konjungtiva antara teknik lem albumin serta jahitan dinilai hari-1 pascabedah oleh seorang dokter hewan yang sudah mendapat pelatihan dari seorang dokter spesialis mata. Setelah satu minggu, mata sebelahnya mendapat perlakuan yang sama seperti mata sebelumnya. Sepuluh menit pascabedah, bola mata kanan dan kiri setiap kelinci dieksenterasi dalam keadaan teranestesi. Dibuat sediaan histologis jaringan konjungtiva 0,5-1 cm dari mata tersebut dengan pewarnaan hematoksilin eosin dan dapat dilihat menggunakan mikroskop cahaya pembesaran 100x oleh seorang dokter ahli histologi. Penilaian didasarkan atas besarnya celah luka (wound gap) cangkok konjungtiva kelinci antara teknik lem albumin dan teknik jahitan pada pengamatan 10 menit dan hari-7 pascabedah. 
Tabel 1 Analisis Derajat Perlekatan Cangkok Konjungtiva Bulbi Mata Kelinci pada Teknik Lem Albumen dan Jahitan Hari-1 Pascabedah

\begin{tabular}{|c|c|c|c|c|c|c|}
\hline \multirow{2}{*}{ Kelompok Perlakuan } & \multicolumn{4}{|c|}{$\begin{array}{c}\text { Banyaknya Mata dengan } \\
\text { Derajat Attachment }\end{array}$} & \multicolumn{2}{|c|}{ Uji Mann-Whitney } \\
\hline & 1 & 2 & 3 & 4 & $\mathbf{Z}$ & $\mathbf{p}$ \\
\hline Teknik lem albumin (8 mata) & 0 & 0 & 0 & 8 & $-3,771$ & 0,000 \\
\hline Teknik jahitan (8 mata) & 0 & 1 & 7 & 0 & & \\
\hline
\end{tabular}

Keterangan: p: nilai kemaknaan; derajat perlekatan 1: persentase penempelan $\leq 25 \%$; derajat perlekatan 2: persentase penempelan $>25 \%$ s.d 50\%; derajat perlekatan 3: persentase penempelan $>50 \%$ s.d. $75 \%$; derajat perlekatan 4: persentase penempelan $>75 \%$

Uji statistik menggunakan uji Mann Whitney dengan pertimbangan ukuran sampel yang kecil $(n=8)$.

\section{Hasil}

Hasil penelitian ini yang dapat dinilai adalah membandingkan derajat perlekatan konjungtiva bulbi pada hari-1 pascabedah serta celah luka (wound gap) pada sepuluh menit dan hari-7 pascabedah antara teknik lem albumin dan jahitan.

Kriteria penelitian perlekatan jaringan cangkok konjungtiva pada dasarnya (sklera) terdiri atas derajat perlekatan 1,2,3, dan 4 dilakukan penelitian pada hari-1 pascabedah.

Tabel 1 memperlihatkan perbedaan derajat perlekatan cangkok konjungtiva bulbi pada hari1 pascabedah secara bermakna antara teknik albumin (derajat 4) dan teknik jahitan (rentang nilai antara derajat 2 dan 3 ) dengan nilai $p=0,000$.
Secara histologis dibandingkan celah luka (wound gap) pada penggunaan teknik lem albumin dan teknik jahitan dengan penilaian dari gambaran mikroskopis diukur celah luka antara jaringan donor dan resipien.

Tabel 2 menunjukkan perbedaan bermakna besar celah luka rata-rata antara teknik lem albumin $(0-0,33 \mu \mathrm{m})$ dan jahitan $(5,33-14 \mu \mathrm{m})$ pada pengamatan sepuluh menit pascabedah dengan nilai $\mathrm{p}=0,0005$.

Tabel 3 menunjukkan terdapat perbedaan bermakna besar celah luka rata-rata antara teknik lem albumin $(0 \mu \mathrm{m})$ dan jahitan $(0,33-$ $4 \mu \mathrm{m}$ ) pada pengamatan hari-7 pascabedah dengan nilai $\mathrm{p}=0,0005$.

Tabel 4 menunjukkan bahwa celah luka untuk teknik lem albumin pada hari-7 pascabedah tidak lebih kecil secara signifikan daripada 10 menit pascabedah dengan nilai $p=0,1425$. Perbedaan (delta) celah luka rata-rata 10 menit pascabedah dengan hari-7 pascabedah untuk teknik lem albumin adalah $0,05-0,00=0,05 \mu \mathrm{m}$. Pada teknik

Tabel 2 Analisis Perbandingan Besarnya Celah Luka antara Teknik Lem Albumin dan Jahitan pada Pengamatan Sepuluh Menit Pascabedah $(\mu \mathrm{m})$

\begin{tabular}{cccc}
\hline Kelinci & $\begin{array}{c}\text { Rata-rata } \\
\text { Lem Albumin } \\
\text { (n=8 mata) }\end{array}$ & $\begin{array}{c}\text { Jahitan } \\
\text { (n=8 mata) }\end{array}$ & p \\
\hline 1 & 0 & 11,67 & $0005^{*}$ \\
2 & 0 & 5,33 & \\
3 & 0 & 14,00 & \\
4 & 0 & 9,67 & \\
5 & 0 & 12,33 \\
7 & 0 & 12,33 \\
8 & 0,33 & 11,00 & \\
\hline
\end{tabular}

Keterangan: p: nilai kemaknaan (Uji Mann Whitney); tanda (-) menunjukkan bahwa lem albumin tidak dapat dihitung besarnya celah luka maka dikeluarkan dari analisis 
Tabel 3 Analisis Perbandingan Besar Celah Luka antara Teknik Lem Albumin dan Jahitan pada Pengamatan Hari-7 Pascabedah $(\mu \mathrm{m})$

\begin{tabular}{cccc}
\hline Kelinci & $\begin{array}{c}\text { Rata-rata } \\
\text { Lem Albumin } \\
\text { (n=8 mata) }\end{array}$ & $\begin{array}{c}\text { Jahitan } \\
\text { (n=8 mata) }\end{array}$ & p \\
\hline 1 & 0 & $4,0005^{*}$ \\
2 & 0 & 0,67 & \\
3 & 0 & 2,67 \\
4 & 0 & 0,33 \\
5 & 0 & \\
6 & 0 & \\
8 & 0 & \\
\hline
\end{tabular}

Keterangan: p: nilai kemaknaan (Uji Mann Whitney); tanda (-) menunjukan bahwa jahitan tidak dapat dihitung besarnya celah luka, maka dikeluarkan dari analisis

jahitan, celah luka pada hari-7 pascabedah lebih kecil dari 10 menit pascabedah. Perbedaan (delta) celah luka rata-rata antara 10 menit pascabedah dan hari-7 pascabedah untuk teknik jahitan adalah 10,88-1,92 = 8,96 $\mu \mathrm{m}$.

Derajat perlekatan cangkok konjungtiva kelinci dengan teknik lem albumin lebih baik daripada jahitan. Berdasarkan atas uji MannWhitney, ternyata derajat perlekatan cangkok konjungtiva bulbi pada hari-1 pascabedah untuk teknik lem albumin secara bermakna lebih baik bila dibanding dengan teknik jahitan (Tabel 1). Hasil uji statistik Mann-Whitney U= 0,000 dan $\mathrm{Z}=-3,771$ dengan peluang kesalahan atau $\mathrm{p}=0,000$. Tampak bahwa $(\mathrm{Z}=-3,771)<(\mathrm{Z}$ Tabel $=1,645)$ atau $p=0,000<\alpha=0,05$ signifikan. Nilai Z tabel diperoleh dari tabel Z normal pada tingkat kesalahan 5\% tipe uji 1-sisi. Temuan ini menunjukkan bahwa penerapan teknik lem albumin untuk cangkok konjungtiva bulbi teruji mampu menghasilkan derajat perlekatan yang lebih baik daripada teknik jahitan pada hari-1 pascabedah.
Celah luka (wound gap) cangkok konjungtiva kelinci dengan teknik lem albumin lebih kecil daripada teknik jahitan.

Hasil uji statistik Mann-Whitney $U=0,000$ dan $\mathrm{Z}=-3,350$ dengan peluang kesalahan atau nilai $\mathrm{p}=0,0005$. Tampak bahwa $(\mathrm{Z}=-3,350)<(-\mathrm{Z}$ tabel $=-1,645)$ atau $p=0,001<\alpha=0.05$ : signifikan. Nilai Z tabel diperoleh dari tabel Z normal pada tingkat kesalahan $5 \%$ tipe uji 1 -sisi. Temuan ini menunjukkan bahwa penerapan teknik lem albumin untuk cangkok konjungtiva bulbi teruji mampu menghasilkan celah luka 10 menit pascabedah yang lebih kecil daripada teknik jahitan.

Hasil uji statistik Mann-Whitney $U=0,000$ dan $\mathrm{Z}=-3,233$ dengan peluang kesalahan atau nilai $\mathrm{p}=0,0005$. Tampak bahwa $(\mathrm{Z}=-3,233)<$ $(-Z$ tabel $=1,645)$ atau nilai $p=0,0005<\alpha=0,05$ : signifikan. Nilai Z tabel diperoleh dari tabel Z normal pada tingkat kesalahan $5 \%$ tipe uji 1-sisi. Temuan ini menunjukkan bahwa penerapan teknik lem albumin untuk cangkok konjungtiva bulbi teruji mampu menghasilkan celah luka

Tabel 4 Analisis Perbedaan Besar Celah Luka antara Teknik Lem Albumin dan Jahitan pada Pengamatan 10 Menit dan Hari-7 Pascabedah

\begin{tabular}{lcccc}
\hline & $\begin{array}{c}\text { Celah Luka } \\
\text { 10 menit Pascabedah }\end{array}$ & $\begin{array}{c}\text { Celah Luka } \\
\text { Hari-7 Pascabedah }\end{array}$ & p & Delta \\
\hline Teknik lem albumin & $0,05 \pm 0,13 \mu \mathrm{m}$ & $0,00 \pm 0,00 \mu \mathrm{m}$ & 0,1425 & $0,05 \mu \mathrm{m}$ \\
Teknik Jahitan & $10,88 \pm 2,59 \mu \mathrm{m}$ & $1,92 \pm 1,73 \mu \mathrm{m}$ & 0,003 & $8,96 \mu \mathrm{m}$ \\
$\mathrm{p}$ & 0,0005 & 0,0005 & & \\
Delta & $-10,83 \mu \mathrm{m}$ & $-1,92 \mu \mathrm{m}$ & \\
\hline
\end{tabular}



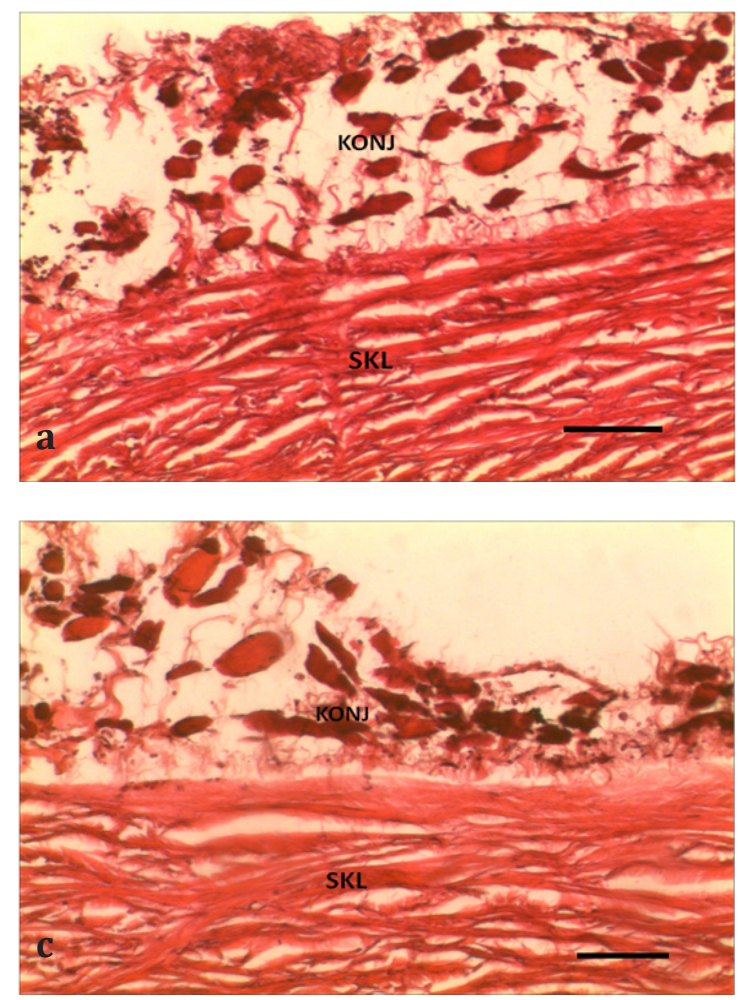
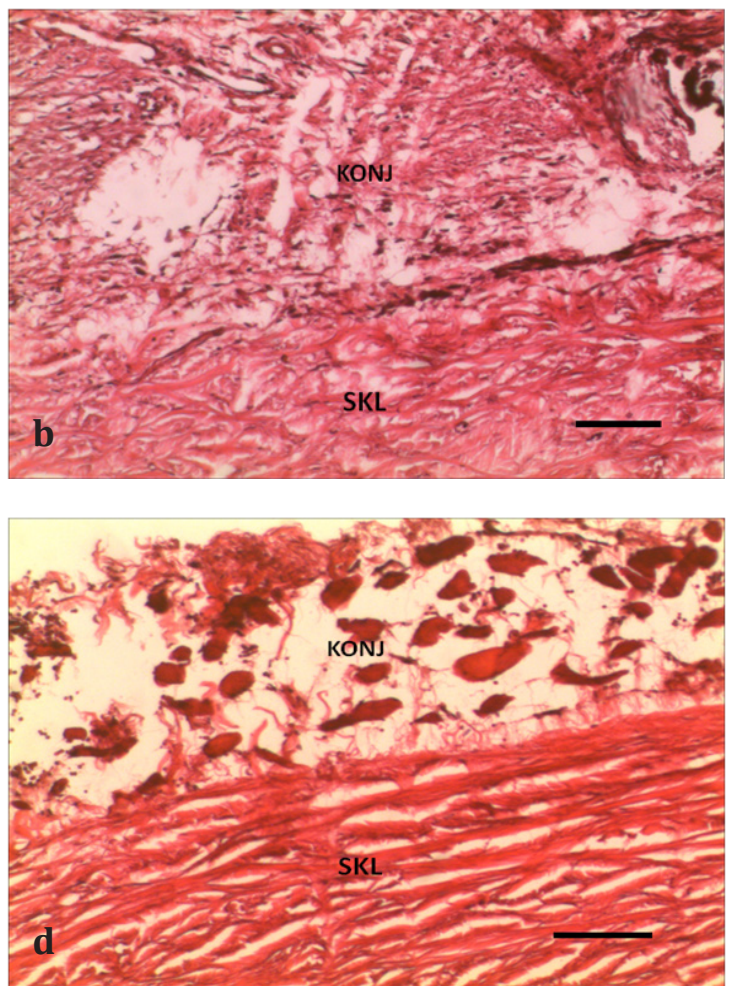

Gambar Gambaran Histologis Penyembuhan Luka. a: histologis penyembuhan luka 10 menit pascabedah pada teknik lem albumin $(0 \mu \mathrm{m})$; b: histologis penyembuhan luka 10 menit pascabedah pada teknik jahitan $(16 \mu \mathrm{m})$; c: histologis penyembuhan luka hari-7 pascabedah pada teknik lem albumin $(0 \mu \mathrm{m})$; d: histologis penyembuhan luka hari-7 pascabedah pada teknik jahitan $(10 \mu \mathrm{m})$.

Keterangan: Konj= konjungtiva; skl= sklera; $B a r=10 \mu \mathrm{m}$

hari-7 pascabedah yang lebih kecil daripada teknik jahitan.

\section{Pembahasan}

Keberhasilan cangkok konjungtiva bulbi sangat dipengaruhi oleh perlekatan jaringan cangkok terhadap dasarnya supaya terjadi vaskularisasi secara optimal dan jaringan cangkok dapat bertahan tetap hidup dengan baik. Penanganan cangkok konjungtiva bulbi menggunakan teknik jahitan mudah robek akibat penarikan jahitan. Simpul jahitan akan merusak jaringan cangkok konjungtiva donor ataupun resipien sehingga manipulasi jaringan yang lebih banyak pada teknik jahitan tersebutmengakibatkan kegagalan adhesi jaringan cangkok dan penyembuhannya berjalan lambat. Lem albumin dapat sebagai alternatif pengganti teknik jahitan. Ovalbulmin yang merupakan protein paling banyak terdapat pada albumin berperan sebagai substrat adhesi yang berfungsi untuk menunjang perlekatan sel sehingga konjungtiva bulbi akan menempel pada dasarnya secara adekuat.,

Penelitian ini mempergunakan albumin yang diambil dari telur bebek. Telur bebek memiliki albumin yang lebih banyak dibanding dengan telur ayam sebanyak $60 \%{ }^{15}$ sehingga diputuskan menggunakan albumin telur bebek. Telur bebek yang dipakai adalah telur bebek berumur kurang dari tiga hari. Huang dkk. ${ }^{10}$ menyatakan ovalbumin akan berangsur-angsur berubah menjadi S-ovalbumin yang memiliki viskositas lebih rendah dan Omana dkk. ${ }^{13}$ menyatakan pula terdapat hubungan perubahan ovalbumin menjadi S-ovalbumin menggunakan pengenceran albumin. Peningkatan S-ovalbumin dipengaruhi oleh $\mathrm{pH}$ dan suhu terhadap lamanya penyimpanan. S-ovalbumin meningkat menjadi 91,24\% pada umur telur 12 hari dengan suhu $37^{\circ} \mathrm{C}$. Peningkatan $\mathrm{pH}$ pada albumin selama penyimpanan tersebut merupakan faktor utama perubahan physicochemical protein albumin 
yang dapat menurunkan viskositas albumin sehingga albumin menjadi encer. ${ }^{10,13}$ Albumin yang encer akan memengaruhi daya rekat.

Pada penelitian ini didapatkan derajat perlekatan cangkok konjungtiva kelinci dengan teknik lem albumin lebih baik daripada jahitan pada pengamatan hari-1 pascabedah $(\mathrm{p}=0,000)$. Belum ada penelitian yang sama seperti pada penelitian ini, namun di dunia medis sudah ada beberapa penelitian yang menggunakan ovalbumin dari albumin untuk merekatkan jaringan tubuh lain seperti penelitian Farrar $\mathrm{dkk}^{14}$ yang menggunakan ovalbumin sebagai rekonstruksi jaringan tulang dan juga dapat meningkatkan penyembuhan tulang dikarenakan merupakan protein biopolimer yang terdiri atas 380 asam amino yang setara dengan 10\% kandungan asam amino pada albumin serum manusia. Penelitian Farrar dkk. ${ }^{14}$ menunjukkan ovalbumin sebagai substrat adhesi jaringan yang memengaruhi pertumbuhan sel, proliferasi, dan diferensiasi sel preostoblas untuk regenerasi jaringan tulang. ${ }^{14}$ Penelitian Kaipparettu dkk. ${ }^{9}$ menunjukkan pertumbuhan sel epitel mammae pada manusia dan tikus dengan menggunakan albumin sebagai media kultur sel tiga dimensi. Hal ini menyatakan albumin memiliki fungsi sebagai ECM yang menunjang pertumbuhan dan juga perkembangan sel. Transglutaminase merupakan enzim dalam sel dan mengikat protein ECM yang berperan dalam adhesi sel. Aktivitas transglutaminase meningkat pada saat terjadi luka sehingga dapat dikatakan bahwa ikatan transglutaminase dan albumin sebagai protein ECM meningkatkan adhesi sel serta akan menyelubungi luka yang berguna untuk melindungi sel dari kerusakan yang lebih lanjut hingga terjadi penyembuhan luka. ${ }^{11}$

Pada penelitian ini perlekatan jaringan pada teknik lem albumin lebih rapat dibandingkan dengan teknik jahitan karena kemungkinan jaringan konjungtiva donor menempel secara merata pada dasarnya tanpa retraksi jaringan.

Trauma bedah yang terjadi bergantung teknik yang dilakukan dan akan berakibat pada penyembuhan jaringan. Injuri akibat insisi operasi pada konjungtiva merupakan ruda paksa matriks ekstraseluler, sel, dan pembuluh darah. Limfosit, monosit, dan makrofag menetap pada daerah inflamasi. Makrofag menarik fibroblas dan dalam waktu yang lama akan memproduksi sejumlah besar kolagen, membentuk massa jaringan fibrosa dengan lambat yang disebut granuloma. ${ }^{3,15}$ Teknik jahitan merupakan trauma tambahan pada cangkok konjungtiva akibat tusukan jarum dan juga merupakan trauma bagi sel, ECM, maupun pembuluh darah, sedangkan benang merupakan benda asing dengan simpul yang dapat menimbulkan iritasi dan inflamasi berlebih pada jaringan. Keadaan ini juga dapat terjadi pada pembentukan granuloma sehingga menghambat penempelan jaringan cangkok dan juga memperlambat penyembuhan luka. ${ }^{3,5}$ Angiogenesis, pertumbuhan, dan juga proliferasi pembuluh darah baru yang merupakan salah satu tanda khusus histologis pada keadaan remodelling jaringan dari inflamasi yang telah disebabkan oleh alergi. ${ }^{16}$

Epitel konjungtiva merupakan epitel yang permeabel karena perlekatan yang erat antara sel epitel dan sel goblet sehingga protein yang diberikan secara topikal akan meresap dengan mudah ke dalam lumen kapiler konjungtiva. ${ }^{17}$ Pada penelitian ini didapatkan hasil celah luka 10 menit dan hari-7 pascabedah untuk teknik lem albumin secara signifikan lebih kecil daripada teknik jahitan. Terdapat enam buah preparat mata dengan teknik lem albumin yang tidak memiliki celah luka pada pengamatan 10 menit pascabedah. Celah luka yang sangat kecil pada satu buah preparat mata dengan teknik lem albumin yang diamati 10 menit pascabedah, mungkin disebabkan oleh saat mengaplikasikan lem albumin yang kurang merata atau terdapat udara sehingga ada bagian cangkok yang tidak menempel dengan baik. Satu buah preparat mata tidak dapat dinilai, mungkin disebabkan oleh albumin yang kental diaplikasikan pada cangkok konjungtiva mengalami perubahan viskositas pada protein akibat perubahan suhu. Albumin merupakan protein yang bersifat termolabil yang dapat mengalami penurunan viskositas sehingga dapat berubah menjadi encer bila terjadi perubahan suhu. ${ }^{13,18}$

Besar celah luka dengan teknik jahitan kemungkinan disebabkan oleh kedua jaringan kurang terpapar dan tidak saling menempel dengan rapat karena disebabkan oleh banyaknya manipulasi sehingga proses adhesi jaringan cangkok dan juga penyembuhan berjalan secara lambat serta menimbulkan celah di antara kedua permukaan jaringan. ${ }^{3}$ Tahapan proses penyembuhan luka meliputi empat tahap, yaitu tahap hemostasis, inflamasi, proliferasi, dan remodelling. Pada tahap awal penyembuhan luka, pembuluh mengalami vasokonstriksi sekitar 10-15 menit, kemudian terjadi vasodilatasi dan peningkatan permeabilitas kapiler sehingga protein plasma dan neutrofil keluar menuju area luka dalam 24 jam diikuti limfosit dan makrofag. Makrofag menghasilkan faktor pertumbuhan dan ECM baru, mempercepat proses angiogenesis 
yang sangat penting untuk proses penyembuhan selanjutnya. Proses epitelisasi, granulasi, dan angiogenesis merupakan proses penting pada tahap proliferasi. Pada tahap pembentukan jaringan granulasi ditandai oleh aktivitas sel fibroblas dan pembentukan pembuluh darah baru. Fibroblas paling aktif berada di tepi luka pada 3-5 hari pascatrauma dan sekitar akhir minggu pertama, serta fibroblas merupakan sel utama pada luka. Jaringan granulasi dibutuhkan untuk mengisi celah luka yang berlangsung selama proses inflamasi dan terus berlangsung sampai dasar luka tertutup serta mencapai keadaan maksimal pada hari kelima pascaluka. Bila terdapat celah luka besar maka jaringan granulasi yang dibutuhkan akan lebih banyak dan banyak terdapat serbukan sel-sel radang serta proses pembentukan jaringan granulasi tersebut akan berlangsung lebih lama. ${ }^{15}$ Keadaan ini dapat dilihat juga pada penyembuhan luka antara teknik lem albumin dan jahitan, yaitu terdapat celah luka yang lebih kecil pada teknik lem albumin dibanding dengan teknik jahitan. Pada penelitian ini hanya mengamati gambaran histologis celah luka (wound gap) antara teknik lem albumin dan jahitan.

Pada fase remodelling terjadi perubahan komposisi matriks ekstraseluler yang seimbang. Ketidakseimbangan yang terjadi merupakan produksi kolagen yang berlebihan oleh fibroblas karena tekanan mekanik dapat memperlambat penyembuhan luka atau jaringan fibrosis lebih sehingga menyebabkan jaringan parut bahkan keloid. ${ }^{15}$ Berdasarkan pada teori tersebut dapat dinyatakan bahwa pembentukan kolagen yang berlebihan oleh fibroblas disebabkan tindakan jahitan akan memperlambat penyembuhan luka atau terbentuk jaringan fibrosis berlebih sehingga celah luka pada teknik jahitan lebih besar daripada teknik lem albumin. Hal ini sesuai dengan hasil penelitian (Tabel 4), yaitu perbedaan (delta) celah luka rata-rata antara 10 menit pascabedah dan hari-7 pascabedah untuk teknik lem albumin adalah $0,05 \mu \mathrm{m}$, sedangkan untuk teknik jahitan adalah 8,96 $\mu \mathrm{m}$. Hal tersebut menunjukkan bahwa celah luka untuk teknik lem albumin lebih kecil dibanding dengan teknik jahitan. Pada teknik jahitan kemungkinan juga belum mengalami epitelisasi lengkap pada pengamatan selama satu minggu disebabkan oleh celah luka pada kelompok teknik jahitan yang menyebabkan proses penyatuan jaringan dan juga vaskularisasi tidak berhasil sehingga cangkok hidup dalam attachment yang longgar. ${ }^{3}$ Simpulan, terdapat derajat perlekatan jaringan cangkok konjungtiva dengan teknik lem albumin lebih baik bila dibanding dengan teknik jahitan serta celah luka (wound gap) antara cangkok konjungtiva dan lapisan sklera di bawahnya pada teknik lem albumin lebih kecil daripada teknik jahitan.

\section{Daftar Pustaka}

1. Huerva V, March A, Alonso MM. Pterygium surgery by means of conjunctival autograft: long term folow-up. Arq Bras Ophthalmol. 2012;75(4):251-5.

2. Rashid H, Rahman F, Khan SB. Results of conjunctival uto-transplant in pterygium surgery. Gomal J Med Sci. 2010;8(1):82-4.

3. Enus S. Peran lem fibrin otologus terhadap penempelan tandur konjungtiva bulbi melalui ekspresi gen fibronektin dan integrin pada mata kelinci [disertasi]. Bandung: Universitas Padjadjaran; 2009.

4. Panda A, Kumar S, Kumar A. Fibrin glue in ophthalmology. Indian J Ophthalmol. 2010;58(2):371-9.

5. Yuksel B, Unsal SK, Onat S. Comparison of fibrin glue and suture technique in pterygium surgery performed with limbal autograft. Int J Ophthalmol. 2010;3(4):316-20.

6. King'ori AM. Uses of poultry eggs : egg albumin and egg yolk. Res J Poult Sci. 2012; 5(2):9-13.

7. Narahari D. In praise of the humble egg. Poultry Int. 2009;9(1):24-6.

8. Campos MS, Hernandez RP, Guerrero LC, Ruelas AC, Tintore SG, Ancona DB. Physicochemical anf functional properties of dehydrated Japanese quail (Coturnix japonica) egg white. Food Nutr Sci. 2013; 4(1):289-98.

9. Kaipparettu BA, Kuiatse I, Tak Yee Chan B, Lee AV, Osterreich S. Novel egg white based 3D cell culture system. Bio Techniques. 2008;45(2):165-71.

10. Huang Q, Qiu N, Ma MH. Estimation of egg freshness using S-ovalbumin as an indicator. Poultry Sci. 2012;91(1):739-43.

11. Kim JY, Park SE, Song KY, Park SC. Glutathione transferase (Class $\pi$ ) expression in pterigia. Korean J Ophthalmol. 1998;12(1):6-13.

12. Jalaludeen A, Churchil RR. Duck eggs and their nutritive value. Poultry Line. 2006;10(1):36-9.

13. Omana DA, Liang Y, Kav NN, Wu J. Proteamic analysis of egg white proteins during storage. Proteomic. 2011;11(1):144-53.

14. Farrar G, Barone J, Morgan A. Ovalbumin 
based porous scaffolds for bone tissue regeneration. J Tissue Engineering. 2010; 20(10):1-6.

15. Li J, Chen J, Kirsner R. Pathophysiology of acute wound healing. Clin Dermatol. 2007; 25(1):9-18.

16. El-Asrar A, Al-Mansouri S, Tabbara $\mathrm{KF}$, Missotten L. Immunopathogenesis of conjunctival remodelling in vernal keratoconjunctivitis. Eye. 2006;20(1):71-9.

17. Dartt DA. The conjunctiva-structure and function. [diunduh 26 Mei 2013]. Tersedia dari: http//www.eyecalcs.com/DAWN/ pages/v8/v8c002.html.

18. Alleoni ACC. Albumin protein and functional properties of gelation and foaming. Sci Agric Braz. 2006;63(3):291-8. 